\title{
Feasibility of rubber (Hevea brasiliensis Muell. Arg.) cultivation in Eastern province of Sri Lanka with the peasant community
}

\author{
S M M Iqbal*, V H L Rodrigo* and P K W Karunathilake* \\ * Rubber Research Institute of Sri Lanka, Dartonfield, Agalawatta, Sri Lanka
}

Received 20 February 2010: Accepted 12 July 2010

\begin{abstract}
Being a war torn area, Eastern province of Sri Lanka is relatively underdeveloped and a large extent of lands which were under chena cultivation is available. Rubber (Hevea brasiliensis Muell. Arg.) has proven to be a successful tree crop in the peasant community with its ability to provide continuous permanent income through latex harvesting. Therefore, a feasibility study of planting rubber in Eastern province was carried out. The area coming under the Intermediate zone was the target and rubber planting commenced in 2003 with the participation of three farmers in Komana village of the Padiyatalawa division in the Ampara district. Only two farmers were successful in the first attempt. However, this success led to plant rubber in over 100ha with 282 farmers in the region by 2008. Despite the dry spell, the survival and growth of rubber plants in most of sites were satisfactory and on average, the annual girth expansion rate was $7.35 \mathrm{~cm}$. Rubber plants were expected to be harvested for latex by 7 years. Photosynthetic parameters under normal circumstances were rather healthy, however, under severe drought conditions they were affected indicating a drought induced photoinhibition or down regulation in photosynthesis. Potential of alleviating the adverse effects of droughts on plant growth using improved agro-management practices is discussed.
\end{abstract}

Key words: dry areas, growth, photosynthesis, rubber, smallholder farmers

\section{Introduction}

In Sri Lanka, the contribution of the rubber industry to the GDP is quite substantial and its share in foreign exchange earning has been over $0.7 \%$ (Anon, 2007). Although more rubber has to be produced to meet the increasing demand, there is virtually no potential for further expansion of the rubber cultivation in its traditional growing areas, i.e. Wet zone, since lands in this region are highly subjected to urbanization and industrialization. Therefore, the Government of Sri Lanka has targeted the Intermediate zone in the south east of the island for future rubber expansion. At present, rubber cultivation south east is known to be 
restricted mainly to two districts; Monaragala and Hambantota comprising less than 6000 hectares of rubber. Annual rainfall in the Intermediate zone is sufficient for rubber growth but the existence of distinct dry seasons means that quality of management practices is far more critical to the successful establishment of the crop compared to the traditional rubber growing regions in Wet zone. Although land capita is generally higher in these two districts than in more developed western region of Sri Lanka, other new potential areas have to be targeted for further expansion of rubber cultivation because of continuous increase in pressure on land with increase in population.

Eastern province has currently been identified for development programmes by the government of Sri Lanka. It comprises large extent of thinly populated land indicating the potential for establishing plantation crops like rubber. Most of lands available for cultivation in this region appeared to be crown lands that had been used for shifting cultivation. These lands could not be reforested without participation of the peasant community. Continuous cultivation of seasonal crops limits the productivity and further, sudden changes in weather pattern (so called climatic variability) affect these poor crops. Therefore, farmers require a secured source of income. Rubber (Hevea brasiliensis Muell.Arg.) has proven to be a successful tree crop in the peasant community with its ability to provide continuous permanent income through latex harvesting. Moreover, being a crop with 30-year lifecycle, rubber cultivation assures farmers' ownership to the land. The majority of people in this area are farmers in the rural sector specially those who are either below or hovering on the poverty line. Therefore, the objective of the present study was to assess the feasibility of planting rubber in Eastern province of the country with the participation of peasant community.

\section{Materials and Methods \\ Rapid appraisal}

A rapid appraisal was initially conducted in 2003 to identify suitable areas for rubber cultivation in this region. The checklist used for the rapid appraisal included parameters such as climatic conditions and soil characteristics (Table 1), farmers' livelihood, land availability for planting rubber, farmers' attitudes on planting rubber, existing cropping systems, functioning of agricultural societies and infrastructure facilities available. A review on climatic conditions of Eastern province was undertaken using a detailed map of agro-climatic zones of Sri Lanka (Fig. 1). The province comprises basically two zones, Intermediate and Dry zones (Anon, 2003). Two soil types, i.e. IBL (Immature Brown Loam) and RBE (Reddish Brown Earth), were predominantly found in the Intermediate zone (Rodrigo et al., 2007). With the perception of that Intermediate zone was better for rubber than the Dry zone, areas under Padiyatalawa and Maha 
Oya Divisional secretariats in the Ampara district were identified for the study. Divisional Secretaries (DS) of those areas were contacted to find out their personal attitudes on planting rubber and to obtain their support for the study.

\section{Establishment of rubber}

Komana village was initially selected from Padiyatalawa. In this village, three farmers were selected for the initial establishment of rubber in consultation of DS of the area. The lands selected for the rubber cultivation, had been assigned for the seasonal crops such as maize, upland rice. Therefore, it was proposed to plant rubber as an intercrop with those traditional crops. Budgrafted polybagged clonal rubber plants from the genotype RRIC 121 were distributed and farmers were advised to do the planting at a spacing of $2.4 \mathrm{~m} \times 8.1 \mathrm{~m}$ with a density of 500 plants per hectare as recommended for elsewhere in Sri Lanka (Attanayaka, 2001). In 2003, only two farmers in Komana were able to cultivate rubber due to the problem of supplying quality planting material. A training programme on the initial establishment and maintenance of rubber was conducted to educate farmers; nevertheless, the management of sites was rather extensive particularly with different levels of weeding and intercropping. In 2006 and 2007, some other farmers in the same village and an adjacent village, Helakomana, joined the rubber cultivation.

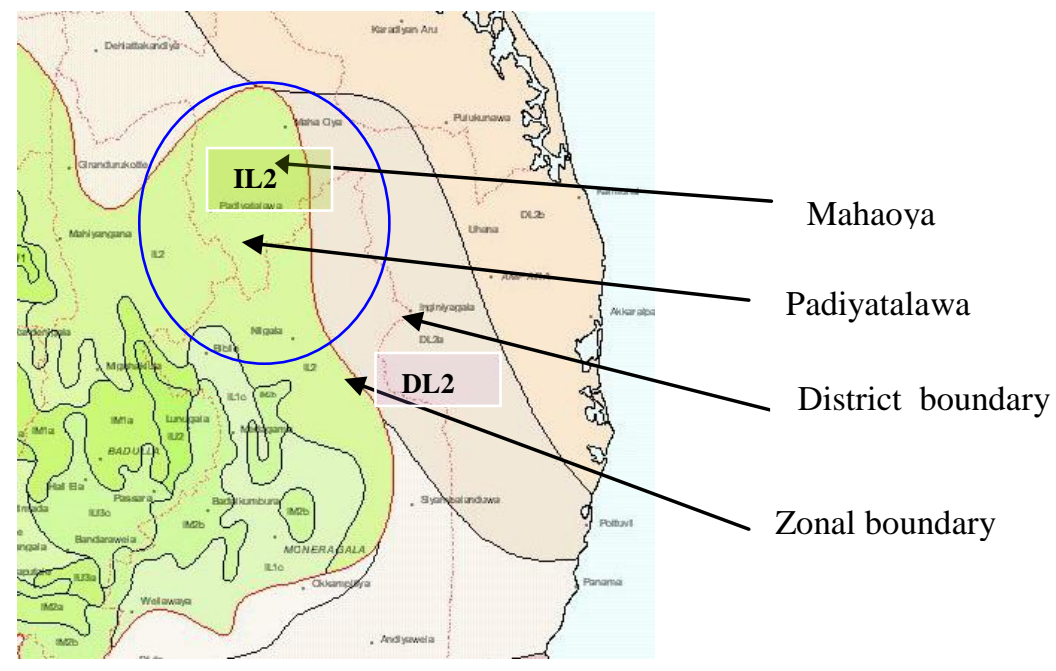

Fig. 1. Agro-climatic zone map showing the areas targeted for initial cultivation of rubber in Eastern province (Anon, 2003) 
S M M Iqbal et al.

Table 1. Soil properties of the selected area for rubber cultivation in the Eastern province

\begin{tabular}{ll}
\hline Soil property & Range \\
\hline $\mathrm{pH}$ & 5.3 to 6.3 \\
Organic Carbon \% & 0.45 to 1.07 \\
Texture & Loamy sand to sandy loam \\
\hline
\end{tabular}

By 2008, rubber cultivation was further expanded to the area under Mahaoya DS covering Harasgala village. The area cultivated with rubber in each year from 2003 to 2008 was 01ha, 08ha, 21ha, 24ha, 27ha and 37ha, respectively (Table 2). Total extent of rubber by the end of 2008 was 118 ha with 282 of families involved.

Table 2. Physical progress of rubber cultivation in the Intermediate zone of Eastern Province

\begin{tabular}{lllcr}
\hline Year of planting & DS division & Village & No. of farmers & Extent (ha) \\
\hline 2003 & Padiyatalawa & Komana & 02 & $\mathbf{1}$ \\
2004 & Padiyatalawa & Komana & 11 & 4.5 \\
2004 & Padiyatalawa & HelaKomana & 08 & 3.5 \\
2005 & Padiyatalawa & Komana & 26 & 10.7 \\
2005 & Padiyatalawa & HelaKomana & 24 & 9.7 \\
2006 & Padiyatalawa & Komana & 25 & 10.1 \\
2006 & Padiyatalawa & HelaKomana & 35 & 14.2 \\
2007 & Padiyatalawa & Komana & 30 & 11.7 \\
2007 & Padiyatalawa & HelaKomana & 33 & 15.8 \\
2008 & Padiyatalawa & Marawa & 13 & 5.3 \\
2008 & Padiyatalawa & Komana & 16 & 6.9 \\
2008 & Padiyatalawa & HelaKomana & 21 & 10.1 \\
2008 & Padiyatalawa & DoraKumbura & 06 & 2.8 \\
2008 & Padiyatalawa & Miriswatta & 02 & 1.2 \\
2008 & Padiyatalawa & Kolamanthalawa & 09 & 3.6 \\
2008 & Padiyatalawa & Thalapitiya & 02 & 1.2 \\
2008 & Padiyatalawa & Khelulla & 07 & 3.2 \\
2008 & Maha Oya & Harasgala & 12 & 4.9 \\
\hline
\end{tabular}




\section{Crop husbandry}

Fertilizer was applied to rubber plants as per the general recommendation given on annual basis by the RRISL. Considering the rainfall pattern of the region, the frequency of fertilizer application was adjusted as three applications per year instead of four in traditional areas. To overcome the dry spell, farmers were advised to apply thick mulch around the plant with the residues of seasonal crops.

\section{Rainfall measurement}

Daily rainfall was monitored from June 2006 onwards using a rain gauge installed in a smallholding in Komana village.

\section{Growth and physiological assessments of rubber}

Girth of the tree at $120 \mathrm{~cm}$ height from the bud-grafted union was measured annually in 20 sites established in 2003, 2004, 2005 and 2006 from the $1^{\text {st }}$ year after planting. Also, the number of plants survived in each site was assessed on yearly basis. Extra plants were supplied to replace the casualties, during the first year of growth.

The light response curves of photosynthesis of rubber were built up annually 3 years from 2006 with field measurements on photosynthetic rates at varying light levels using a portable open system infra-red gas analyser (IRGA) (LI-6400, Li-Cor Inc., Lincoln, NE, USA.) in 2 sites established in 2003 and in 3 sites established in 2004 and 2005 (one from each year). Two sets of measurements were made in each plant, one in the morning (between $0900 \mathrm{~h}$ and $1000 \mathrm{~h})$ and the next in the evening (between 1500h and 1600h) during the periods of March-April. In the year 2007, another set of measurements was made in a severe dry period. Using the software Photosynthesis Assistant, Ver. 1.1.2., light saturated rate of photosynthesis $\left(\mathrm{A}_{\max }\right)$ and the apparent quantum yield of rubber $\left(\phi_{\text {app }}\right)$ were derived from light response curves. All measurements were confined to most recently matured leaves which generally showed the highest rate of photosynthesis.

Further, for the purpose of investigating the potential photoinhibition in leaf photosynthesis, chlorophyll $a$ fluorescence was measured with Plant Efficiency Analyser (PEA, Hansatech Instruments Ltd., England. UK) in terms of the ratio of variable $\left(\mathrm{F}_{\mathrm{v}}\right)$ to maximal $\left(\mathrm{F}_{\mathrm{m}}\right)$ fluorescence of dark-adapted rubber leaves. Measurements were made along with the assessments of photosynthesis, except in 2007 dry period.

\section{Results}

According to the rainfall data collected during the trial period (Fig. 2), total rainfall received during the year 2007 and 2008 was $1167 \mathrm{~mm}$ and $2529 \mathrm{~mm}$, respectively. There was a distinct dry period from May to September showing unimodel rainfall pattern in the area. The highest rainfall of $457 \mathrm{~mm}$ was recorded in the month of January 2008 whilst there was no any rain in June 
2009. Virtually, there was no rain in the month of June in 2009. Average rainfall per month was $138 \mathrm{~mm}$ during the study period.

During the first year of growth, a mean survival rate of $c a .75 \%$ was achieved (Table 3). Nevertheless, some farmers were able to maintain a survival rate as high as $100 \%$ whilst the lowest rate recorded was 55\%. However, most of casualties during the first two months were replaced with the extra plants supplied to farmers. Mean tree girth at $120 \mathrm{~cm}$ height achieved after a year of growth varied from $3.14 \mathrm{~cm}$ to $10.66 \mathrm{~cm}$ in smallholdings (Table 4). After five years of growth, rubber trees planted in year 2003 were able to reach a mean girth of $37.37 \mathrm{~cm}$ with a survival rate of ca. $90 \%$. Girth expansion rate showed a marginal increase with the age of plants (Fig. 3). However, assuming a linear growth in the study period, annual average girth expansion rate of $7.35 \mathrm{~cm}$ was observed as the mean for all sites under consideration (Fig. 3).

The light saturated rate of photosynthesis $\left(\mathrm{A}_{\max }\right)$ was comparatively lower in the afternoon than in morning hours and this was common to all age categories. Within a set of measurements, trees planted early showed higher values of $A_{\max }$ (Table 5). Quantum yield of photosynthesis $\left(\phi_{\text {app }}\right)$ in the morning was also higher than that in the afternoon and remained over 0.035. Nevertheless during the severe dry period (August 2007), $\mathrm{A}_{\max }$ fell down to the values below $4 \mu$ mol m ${ }^{-2} \mathrm{~s}^{-1}$ and also, $\phi_{\text {app }}$ was at or below 0.03 (Table 6). The drop in $\phi_{\text {app }}$ was more evident in trees planted in 2005 with values below 2 .

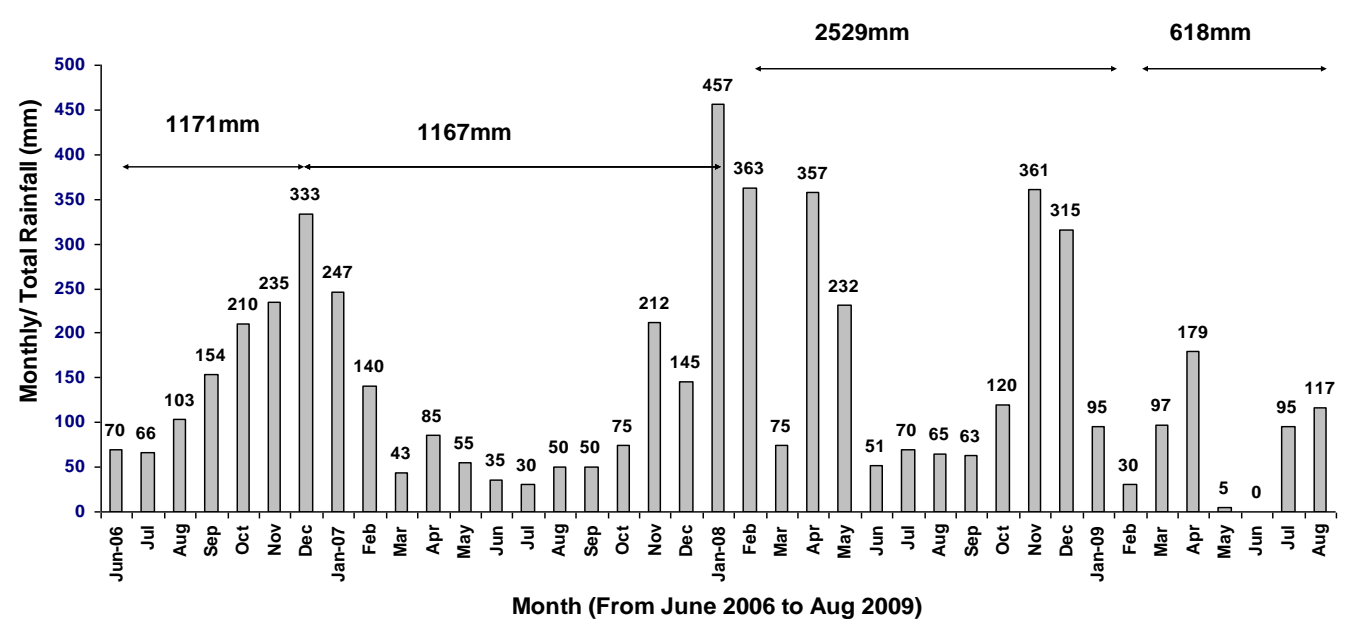

Fig. 2. Monthly rainfall distribution in Komana village, the centre village for rubber cultivation in Eastern province. Total rainfall received in different calendar years of the study period is also indicated 
Table 3. Early establishment of rubber plants in Eastern province. Survival rates recorded after a year of growth

\begin{tabular}{clcccc}
\hline $\begin{array}{c}\text { No. of } \\
\text { holdings }\end{array}$ & Village & $\begin{array}{c}\text { Year of } \\
\text { Planting }\end{array}$ & $\begin{array}{c}\text { Maximum survival } \\
\text { rate }(\%)\end{array}$ & $\begin{array}{c}\text { Minimum } \\
\text { survival } \\
\text { rate }(\%)\end{array}$ & $\begin{array}{c}\text { Mean } \\
\text { survival rate } \\
(\%)\end{array}$ \\
\hline 02 & Komana & 2003 & 100 & 89 & 94.5 \\
03 & Komana & 2004 & 100 & 44 & 77.3 \\
03 & Komana & 2005 & 100 & 69 & 86.3 \\
03 & Komana & 2006 & 100 & 100 & 100.0 \\
03 & Hela Komana & 2004 & 89 & 45 & 74.3 \\
03 & Hela Komana & 2005 & 76 & 38 & 54.6 \\
03 & Hela Komana & 2006 & 100 & 100 & 100.0 \\
\hline
\end{tabular}

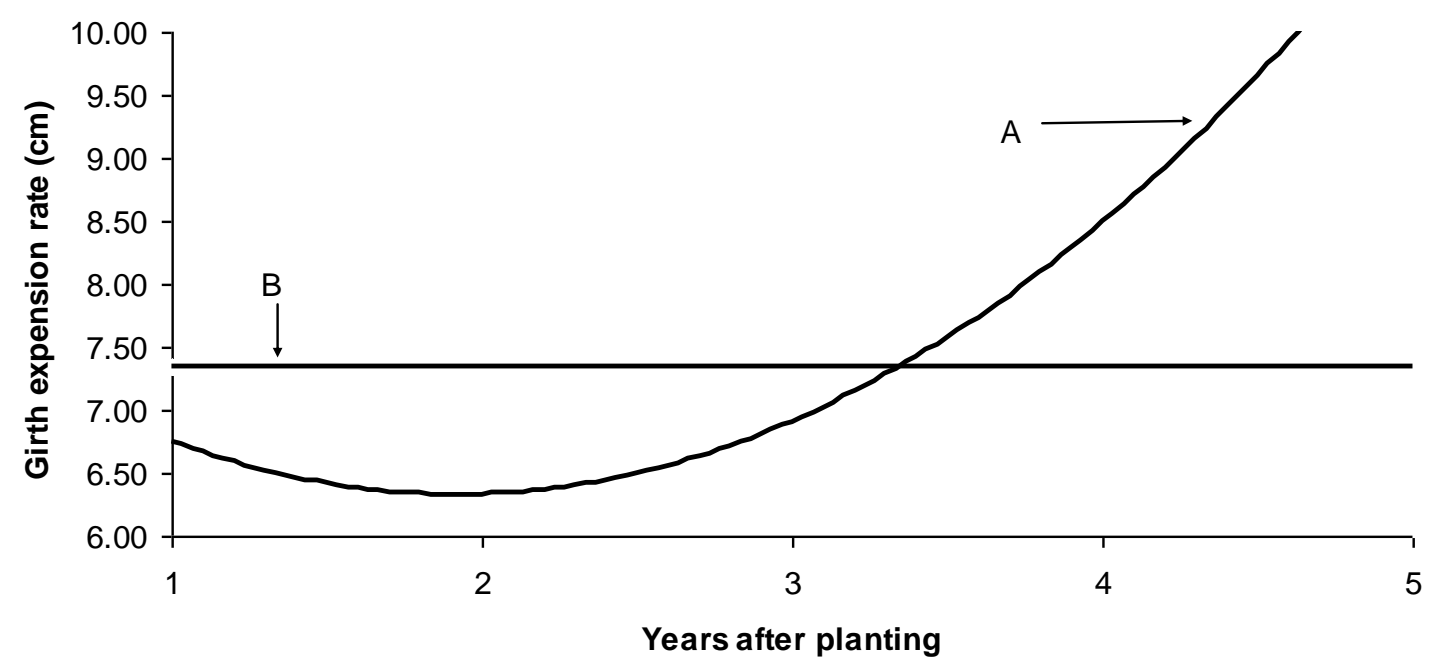

Fig. 3. Girth expansion rate of rubber in the intermediate zone of Eastern province. ' $A$ ' represent the mean girth expansion rate for the particular year whilst line ' $\mathrm{B}$ ' represents the value if the growth is assumed to be linear over the study period 
S M M Iqbal et al.

Table 4. Girth of rubber plants at $120 \mathrm{~cm}$ height. Values are given as mean girth all the smallholdings planted in the particular year (with \pm Standard Error). YAP refers to the years after planting

\begin{tabular}{rrrrrrr}
\hline $\begin{array}{r}\text { Year of } \\
\text { Planting }\end{array}$ & \multicolumn{5}{c}{ Mean girth (cm) } \\
\cline { 2 - 7 } & 1 YAP & \multicolumn{1}{c}{ 2 YAP } & 3 YAP & 4 YAP & 5 YAP \\
\hline 2003 & $5.08 \pm 0.245$ & $14.88 \pm 0.326$ & $23.52 \pm 0.583$ & $29.49 \pm 0.636$ & $40.07 \pm 0.802$ \\
2003 & $5.75 \pm 0.418$ & $12.26 \pm 0.288$ & $18.04 \pm 0.373$ & $23.31 \pm 0.392$ & $34.72 \pm 0.657$ \\
2004 & $4.13 \pm 0.116$ & $20.34 \pm 0.395$ & $28.09 \pm 0.556$ & $39.75 \pm 0.789$ & - \\
2004 & $5.07 \pm 0.116$ & $14.74 \pm 0.364$ & $21.07 \pm 0.454$ & $32.75 \pm 0.673$ & - \\
2004 & $5.02 \pm 0.092$ & $15.01 \pm 0.528$ & $20.32 \pm 0.723$ & $29.07 \pm 0.897$ & - \\
2005 & $8.64 \pm 0.395$ & $12.48 \pm 0.434$ & $20.31 \pm 0.793$ & & - & - \\
2005 & $9.37 \pm 0.235$ & $12.88 \pm 0.304$ & $23.65 \pm 0.488$ & & - \\
2005 & $10.66 \pm 0.221$ & $11.89 \pm 0.234$ & $21.69 \pm 0.375$ & & - \\
2006 & $7.10 \pm 0.233$ & $16.10 \pm 0.298$ & & - & - \\
2006 & $6.76 \pm 0.246$ & $12.30 \pm 0.233$ & & - & - \\
2006 & $4.71 \pm 0.215$ & $14.00 \pm 0.1965$ & & & - \\
2004 & $4.99 \pm 0.110$ & $12.61 \pm 0.246$ & $18.30 \pm 0.368$ & $22.98 \pm 0.571$ & - \\
2004 & $3.14 \pm 0.080$ & $8.33 \pm 0.279$ & $16.60 \pm 0.390$ & $21.66 \pm 0.621$ & - \\
2004 & $3.32 \pm 0.078$ & $10.18 \pm 0.283$ & $12.80 \pm 0.469$ & $28.17 \pm 0.466$ & - \\
2005 & $9.20 \pm 0.211$ & $13.30 \pm 0.367$ & $17.00 \pm 0.517$ & & - \\
2005 & $5.25 \pm 0.202$ & $9.90 \pm 0.350$ & $14.17 \pm 0.400$ & & - \\
2005 & $8.01 \pm 0.271$ & $13,20 \pm 0.300$ & $22.70 \pm 0.372$ & & - \\
2006 & $7.39 \pm 0.185$ & $13.10 \pm 0.216$ & & - & - \\
2006 & $6.54 \pm 0.311$ & $13.00 \pm 0.254$ & & & - \\
2006 & $5.75 \pm 0.149$ & $15.90 \pm 0.335$ & & - & - \\
\hline
\end{tabular}

The time-course variation in chlorophyll $a$ fluorescence emission, expressed as the ratio of variable to maximum fluorescence $\mathrm{F}_{\mathrm{v}} / \mathrm{F}_{\mathrm{m}}$, is shown in Table 7 . Although the $F_{v} / F_{m}$ ratio were greater in the morning than in afternoon, the absolute difference was marginal. In most occasions, $\mathrm{F}_{\mathrm{v}} / \mathrm{F}_{\mathrm{m}}$ ratio was ca. 0.8 and always above 0.7. There was no significant difference in the $\mathrm{Fv} / \mathrm{Fm}$ ratio of young and old plants. 
Planting rubber in Eastern province of Sri Lanka

Table 5. Light-saturated rate $\left(A_{\max }\right)$ and apparent quantum yield $\left(\phi_{\text {app }}\right)$ of photosynthetic $\mathrm{CO}_{2}$ assimilation of rubber. Measurements were made in the wet period

\begin{tabular}{|c|c|c|c|c|c|c|c|}
\hline \multirow[t]{2}{*}{$\begin{array}{l}\text { Year of } \\
\text { measure } \\
\text {-ment }\end{array}$} & \multirow[t]{2}{*}{ Time of measurement } & \multicolumn{2}{|c|}{$\begin{array}{l}\text { Rubber planted } \\
\text { in } 2003 \\
\text { November }\end{array}$} & \multicolumn{2}{|c|}{$\begin{array}{l}\text { Rubber planted } \\
\text { in } 2004 \\
\text { November }\end{array}$} & \multicolumn{2}{|c|}{$\begin{array}{l}\text { Rubber planted in } \\
2005 \text { November }\end{array}$} \\
\hline & & 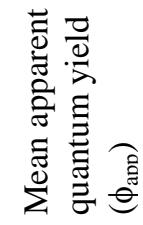 & 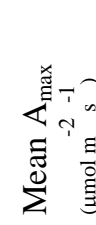 & 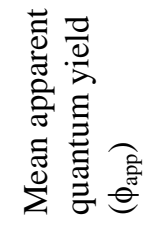 & 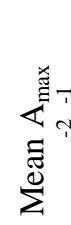 & 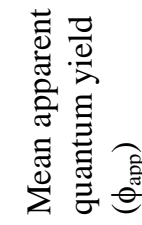 & 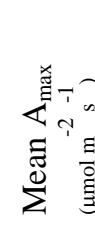 \\
\hline \multirow[t]{2}{*}{2006} & Morning (0900-1000h) & 0.063 & 17.4 & 0.059 & 15.2 & 0.051 & 13.1 \\
\hline & Afternoon (1500-1600h) & 0.049 & 13.6 & 0.039 & 12.2 & 0.042 & 12.2 \\
\hline \multirow[t]{2}{*}{2007} & Morning (0900-1000h) & 0.037 & 14.3 & 0.043 & 13.5 & 0.042 & 11.2 \\
\hline & Afternoon (1500-1600h) & 0.031 & 6.9 & 0.033 & 8.7 & 0.017 & 8.5 \\
\hline \multirow[t]{2}{*}{2008} & Morning (0900-1000h) & 0.054 & 17.4 & 0.050 & 16.3 & 0.053 & 16.0 \\
\hline & Afternoon (1500-1600h) & 0.045 & 16.3 & 0.048 & 15.5 & 0.050 & 15.2 \\
\hline
\end{tabular}

Table 6. Light-saturated rate $\left(A_{\max }\right)$ and apparent quantum yield $\left(\phi_{\text {app }}\right)$ of photosynthetic $\mathrm{CO}_{2}$ assimilation of rubber. Measurements were made in a distinct dry period

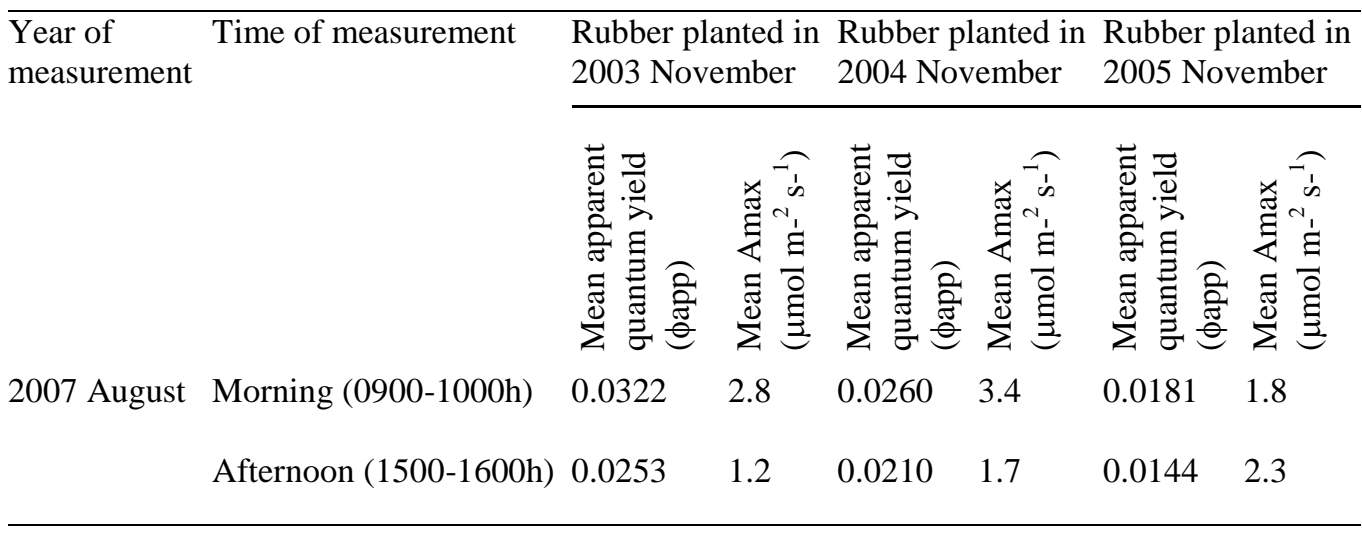

Discussion

The area considered for planting rubber belongs Ampara district and covers two Pradeshiya Sabhas, Padiyatalawa and Maha Oya (Fig.1). Padiyatalawa owns 75 villages in 20 Gramasevaka (GS) divisions with a population of 16,970 in 3970 families, whilst $c a$. 30,000 people are living in 90 villages of 17 GS divisions in Maha Oya (Rodrigo et al., 2007). According to the Divisional Secretaries of both Divisional 
S M M Iqbal et al.

Table 7. Leaf chlorophyll a fluorescence emission Fv/Fm ratio of rubber planted in the years 2003, 2004 and 2005. Measurements made in the wet period

\begin{tabular}{|c|c|c|c|c|c|c|c|}
\hline \multirow[t]{2}{*}{$\begin{array}{l}\text { Year of } \\
\text { measurement }\end{array}$} & \multirow[t]{2}{*}{$\begin{array}{l}\text { Time of } \\
\text { measurement }\end{array}$} & \multicolumn{2}{|c|}{$\begin{array}{l}\text { Rubber planted in } \\
2003 \text { November }\end{array}$} & \multicolumn{2}{|c|}{$\begin{array}{l}\text { Rubber planted in } \\
2004 \text { November }\end{array}$} & \multicolumn{2}{|c|}{$\begin{array}{l}\text { Rubber planted in } \\
2005 \text { November }\end{array}$} \\
\hline & & $F v / F m$ & $\mathrm{SE} \pm$ & $F v / F m$ & $\mathrm{SE} \pm$ & $F v / F m$ & SE \pm \\
\hline \multirow[t]{2}{*}{2006} & $\begin{array}{l}\text { Morning } \\
(0900-1000 \mathrm{~h})\end{array}$ & 0.811 & 0.006 & 0.814 & 0.004 & 0.780 & 0.007 \\
\hline & $\begin{array}{l}\text { Afternoon } \\
(1500-1600 \mathrm{~h})\end{array}$ & 0.790 & 0.013 & 0.806 & 0.007 & 0.777 & 0.004 \\
\hline \multirow[t]{2}{*}{2007} & $\begin{array}{l}\text { Morning } \\
\text { (0900-1000h) }\end{array}$ & 0.811 & 0.006 & 0.793 & 0.012 & 0.755 & 0.010 \\
\hline & $\begin{array}{l}\text { Afternoon } \\
(1500-1600 \mathrm{~h})\end{array}$ & 0.797 & 0.010 & 0.790 & 0.011 & 0.736 & 0.010 \\
\hline \multirow[t]{2}{*}{2008} & $\begin{array}{l}\text { Morning } \\
(0900-1000 \mathrm{~h})\end{array}$ & 0.846 & 0.004 & 0.841 & 0.002 & 0.817 & 0.007 \\
\hline & $\begin{array}{l}\text { Afternoon } \\
(1500-1600 \mathrm{~h})\end{array}$ & 0.835 & 0.005 & 0.825 & 0.006 & 0.809 & 0.012 \\
\hline
\end{tabular}

Secretariats, $c a .95 \%$ of the community comprised of fulltime farmers. Majority of them were growing seasonal crops such as cowpea, maize, pumpkin, upland paddy, chilies, banana under rain-fed condition. Major perennial crops grown were lime, orange, mango, teak and coconut. On average, each family owned $c a .1 .2-1.6$ ha of land (Rodrigo et al., 2007). Land use in the selected study area, i.e. Helakomana GS division, covers both Komana and Helakomana villages of Padiyatalawa and is dominated by forests, short-term crops and home garden crops, according to the Gramasevaka (GS). Despite 118 ha planted with rubber, a large extent of uncultivated lands was found in this village and cultivation of permanent crops confined to 166 hectares. By the end of this study period, the majority of households were engaged in rubber cultivation. Land availability in the Helakomana GS division exceeds 400 ha (Iqbal and Rodrigo, 2006). Assuming that $75 \%$ of those lands could be cultivated with rubber, 300 ha of rubber can be planted in this GS division. Assuming a similar situation in other GS divisions, rubber could be cultivated in over 10,000 ha in the villages (37 GS divisions) coming under Padiyatalawa and Maha Oya Divisional secretariats (mostly the intermediate zone) of Eastern province.

Growth of rubber was satisfactory in most of the sites indicating the agronomic suitability of the crop to the area concerned. For all sites and for every year, the rate of girth expansion of rubber in the smallholdings was 7.35 $\mathrm{cm}$ per year. The normal girth expansion rate in the traditional rubber growing areas of the country, i.e. wet 
zone, with the good crop management, is about $10 \mathrm{~cm}$ per year reaching the tappable girth of $50 \mathrm{~cm}$ within 5 years. Nevertheless, a few sites in this area recorded similar rate, whilst most sites were in the range of $8 \mathrm{~cm}$ per year (with that tapping begins after 6 years of growth). Girth expansion rate of rubber in some smallholdings in wet zone is even less than the Eastern province due to poor management conditions and so farmers have to wait over seven years to harvest latex. With the present rate of plant growth, the majority of rubber holdings in Komana and Helakomana could be tapped before 7 years. In years to come, farmers will undoubtedly be much competent in rubber cultivation and able to maintain the required rate of plant growth.

Although there was no soil mapping done in individual sites, the area concerned predominantly belongs to the soil groups of IBL and RBE (Panabokke, 1996). Some chemical properties such as soil $\mathrm{pH}$ and organic carbon were in a range acceptable for rubber cultivation (Rodrigo et al., 2007). Despite the need of detail analyses on soil properties to understand their association on growth of rubber plants, observations made in the present study do not prevent, instead encourage farmers to grow rubber in this region.

Although girth expansion of rubber trees was generally found to be more or less linear during the study period, analysis on girth expansion rates over the time shows that it was higher third year onward than in first two years (Fig.
3). This would mean that plants take over a year for proper acclimatization in this new environment and then with substantial development in the foliage and root system, plants gain a higher growth rate. In the wet zone, rubber plants generally show the highest girth expansion rate within three to four years (Rodrigo et al., 2005). However, in the intermediate zone of Eastern province, rubber plants seem to take little longer to achieve the highest growth rate as observed here.

The potential capacity of the leaf to assimilate $\mathrm{CO}_{2}$ (Amax) is dependent upon the quantity of photosynthetic apparatus, pigment present and water status of the leaf. Higher $A_{\max }$ in older plants is an indication of the adaptation of plants to the environment with the age. Most probably, deep penetration of roots in older plants would maintain the healthy status of the leaves showing high $\mathrm{A}_{\max }$. However, lower $\mathrm{A}_{\max }$ in the severe dry period indicates temporary depression in photosynthesis, which later recovers in wet periods. Further, high level of $\mathrm{Fv} / \mathrm{Fm}$ ratio is indicative of no damages to the photosynthetic apparatus under normal circumstances. Although no fluorescence measurements were made during the severe dry period, very low level of quantum yield (i.e. < 0.02) in plants below two years indicates that there would be a drought induced photoinhibition or down regulation in photosynthesis in this region, i.e. under low level of soil moisture and high radiation loads). This could be 
alleviated to some extent with good agromanagement practices. For instance, the shades established by growing taller intercrops such as banana and maize would be beneficial in this regard. Also, mulching around rubber plants with the residues of these crops will conserve the soil moisture.

The dry period in this region generally prevails from May to September in each year. Therefore, planting with the onset of Northeast monsoon is essential to provide sufficient time for plants to establish in the field before the subsequent dry period. Further, moisture conservation is of utmost importance. Less casualties experienced during the study by some farmers who employed such conservative measures provided a strong proof, encouraging other farmers too to do so. Further, though not tested so far, rainwater harvesting techniques (e.g. ditches) and low cost irrigation techniques (e.g. pitcher irrigation) where possible, may also be useful.

According to the previous socioeconomic studies on the rubber cultivation in this area (Rodrigo and Iqbal, 2006), land availability and farmers' interest to grow rubber were recognized as the greatest strength for successful rubber cultivation. If a family cultivates 1 ha of rubber, it would be capable of producing ca. 150 $\mathrm{kg}$ of rubber per month. This will bring an income of $c a$. Rs.30,000. This appears to be a realistic target and will undoubtedly help to stabilize the livelihood of resource-poor farmers in the area. Further, there will be a large amount of direct and indirect beneficiaries such as traders, manufacturers and casual workers. Therefore, whilst educating and encouraging farmers in Eastern province to grow rubber, their participation is to be obtained to develop simple techniques to minimize the effect of drought on initial plant growth. Such attempts will also help to expand the rubber cultivation beyond the intermediate zone and to the dry zone too.

Soil properties of the sites selected for initial cultivation were found to be suitable for planting rubber with correct soil management practices. The soil $\mathrm{pH}$ in these areas appears to be at the high level of the optimum range for the growth of rubber. The level of organic carbon in these soils appeared to be low, however this could be adjusted by applying organic materials. Addition of organic matter will not only improve the soil fertility but also help to reduce the potential moisture stress on rubber plants during the dry spells. Unless burnt out, stubbles and other leftovers of the harvests in seasonal crops are generally available and could be used as mulch to the rubber plants. This will help to preserve the moisture and in long run, add organic matter to the soil improving the soil structure.

\section{References}

Anon (2003). Map of Agro-Ecological Regions of Sri Lanka. Natural 
Resources Management Centre. Department of Agriculture, Sri Lanka.

Anon (2007). Annual Report, Central Bank of Sri Lanka, Colombo, Sri Lanka.

Anon (2008). Plantation Sector Statistical Pocket Book, Planning Unit of the Ministry of Plantation Industries, Colombo, Sri Lanka.

Attanayaka, D P S T G (2001). Clones for commercial planting in Sri Lanka. In: Handbook of Rubber Volume 1 Agronomy, pp. 86-96 (Eds. L M K Tillekeratne and A Nugawela), Rubber Research Institute of Sri Lanka, Dartonfield, Agalawatta, Sri Lanka.

Panabokke, C R (1996). Soils and AgroEcological Environments of Sri Lanka. Natural Resources, Energy \& Science Authority, Sri Lanka. pp. 220.

Iqbal, S M M and Rodrigo, V H L (2006). Feasibility of rubber (Hevea brasiliensis Muell. Arg.) cultivation in the Eastern Province of Sri Lanka; a non traditional area for rubber, Pre prints. International Rubber Conference Nov. 2006, Ho Chi Minch City, Vietnam P. 571-584.

Rodrigo, V H L, Stirling, C M, Silva, T U $\mathrm{K}$ and Pathirana, P D (2005). The growth and yield of rubber at maturity is improved by intercropping with banana during the early stage of rubber cultivation. Field Crops Research 91, 2333.

Rodrigo, V H L and Iqbal, S M M (2006). Rubber (Hevea brasiliensis Mull. Arg.) cultivation in the Eastern province of Sri Lanka with alleviation of rural poverty and increase in forest cover; a feasibility study. Abstracts of the International Conference on Humid Tropical Ecosystems: Changes, Challenges, Opportunities, December 2006. Kandy, Sri Lanka, 75.

Rodrigo, V H L, Iqbal, S M M, Dharmakeerthi, R S, Karunasekera, K B A and Nugawela, A (2007). Feasibility of expanding rubber (Hevea brasiliensis Muell. Arg.) cultivation to the Eastern province of Sri Lanka. Journal of National Institute of Plantation Management 22, 25-36.

Rodrigo, V H L and Iqbal, S M M (2009). Rubber reaches east; Hand in hand with regaining Sri Lanka. Bulletin of the Rubber Research Institute of Sri Lanka $\mathbf{5 0}$ 111-117.

Address for correspondence: Dr S M M Iqbal, Agronomist, Rubber Research Institute of Sri Lanka, Dartonfield, Agalawatta, Sri Lanka.

e-mail: smmiq@sltnet.lk 